\title{
兵頭先生と良導絡(5)
}

\section{H 肃みと人生}

編 集 部 編

医療器械の販売にあたっている社員たちを集 めて、年何回加医学講演会をやる「スクーリン グ」というシステムがあります。

昭和60年 3 月 15 日、近畿地区スクーリングが 中之島公会堂で開かれ、その講師として痛みの 話を 1 時間余りにわたって行いました。

素人ですが、パラメデイカルの一種といえる てのような人たちを対象に、どの程度のレベル で話をするかが、なかなか難しいのですが、全 文を紹介いたします。四は、そのときに使った スライドの一部です。

\section{1.痛みは䇾告信号}

痛みというものは、人間にとって非常に苦痛 であります。そういう嫌な疼痛感覚というもの が、なぜ人間に備っているのでしょうか。

たとえばお湯に手を入れて、だんだん温度を 上げていくと、熱いという感じになり、さらに 熱くすると、痛いという感じになって、手を引 っ込めてしまう(図 1)。との疼痛感覚というの は、皮庙の温度が45度Cになると起とります。

そしててれは冷い場合であ、そのほかの刺激 の場合であ同じで、要するにそれが組織を破壊

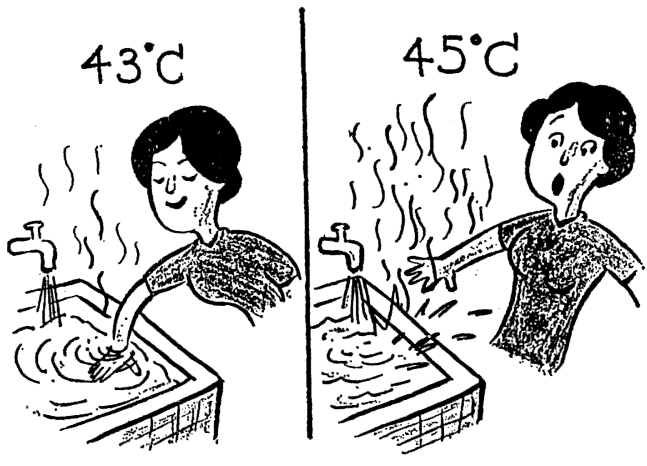

図 1
する寸前になると疼痛を感して、手を引っ込め るわけで、そのおかげで怪我をしないですむわ けです。

そとで疼痛感覚というすのは、「非可逆的な 障害が加わる寸前のととろて、感じられる生体 に不可欠な防御反応である」と定義されます。 つまり生体にはなくてはならない一種の警告装 置なのです。

先天性無痛症という珍しい病気がときどきあ ります。生まれたときから痛覚がない。そうい う子は痛みがないから、自分で自分の指を蹈み 切ってしまったり、危害から逃げるととがない から、怪我をしょっちゅうして、そてからばい 菌がはいって敗血症になって、結局は夭逝をし てしまいます。

\section{2.埆みについての踶解}

このように痛みの感覚というのは、生体に之 って警報装置として大切なのですが、その有用 性の面の方が強調され過ぎて、従来痛みについ て多くの誤解がありました。

たとえば「痛みがある場合、それを止めると 害があるのではないか」とか、「痛みがあると とによって、生体の反応がおてり病気が治るの だ」とか、あるいは、「痛みを止めることは神 さまのみがやるべきととで、人間がやってはい けないのだ」とか、そういう考え方すら実際に かつてはあったのです。

19世紀の半ばでろ、エジンバラ大学の産婦人 科教授シンプソンは拉産の痛みを麻酔で和らげ ました。無痛分婏をはじぬて試みたのです。と とろがローマ法王が、「痛み、特にお産のとき の痛みは神さまが授けたものだ」として、それ に猛烈に反対したのです。痛みというあのは、 取ってはいけないあのだという感情があった時 
代が、つい最近まであったわけです。

現在でも医師の間ですら、「痛みというのは、 二次的な感覚にしか過きない。病気を治せば、 痛みはそれにしたがって自然に取れていくすの だから、そんなるのはむしろほおっておいたほ うが自然的でいい」といったとんでもない認識 か、いまだにかなり広く存在しています。痛み が病気の治りをおくらせ、精神的にもいかに大 きな影響を及ほしているかというととが、過小 評価されているわけです。

\section{3. 痛みの惠咶嫄}

痛みというのはいま言いましたように警報装 置サイレンですが、そのサイレンの音が大きい ほど、その異常を無視しないととになるから、 サイレンを大きく鳴らそうと生体は努めるので す。

痛みの刺激が血管の収縮を起とし、そのため に組織に酸素欠乏が起とり、その組織に異常代 謝産物一発痛物質ができて、ますますその部分 の痛みが増大する。とれを痛みの悪循環と言い ますが、痛みがあると、その痛みを悪化させる 方向に、痛み自身が仕向けていくわけです。

そういうふうにだんだんサイレンの音を大き くして、何を生体に 要求しているのかという と、結局、「休め」というととなのです。そとで 仕事をやめて休めば、血液の循環も良くなり、 筋肉すほぐれていきますから、痛み、つまり病 気が治る方向に向かっていきます。犬なんか見 ていると、痛みがあると徹底的にじっとしてい ます。

しかし文明を持った人間は、休むだけではな い、より有効な方法で、早く痛みを治すととが できるわけです。

なお生体はもともと、何か異常があるとき、 それを治そうとする強力な力を持っています。 てれをホメオステーシスー自然治㿈力と言って います。てれをうまく引き出すととが医療とい うすのです。たから医者が患者さんを治してい るのではない。治る方向に仕向けているだけな のです。そしてそういう方向に仕向けてやれ ば、痛みの悪循環が取れて、それが治るわけで す。

\section{4. 䔡性痛と慢性庸}

痛みには急性痛と慢性痛とがあって、とれは 根本的に遣います。

病気になった場合早期治癔というのが、あら ゆる場合に大切なのですか、ひとたび急性疼痛 というすのが治り切らずに、慢性疼痛に移行す ると、痛みそのものが今度は病気になってきま す。

たとえばヘルペス後神経痛といって、特に老 人の場合はヘルペスが治ったあと神経痛で悩む 方か、二人に一人以上はいます。

はじめに適切な治療をやれば、急性期は痛い けれど、後遺症を残さず、1カ月ぐらいですっ かり治る。ところが良い治療をしないと、帯状 疮疹は治っても、神経痛が残ってしまう。てれ がなかなか治らない。

ヘルペスになったときの痛みは、警告信号で すから、それで患者さんはお医者さんに行くわ けですからいいのですが、そのへルペスが治っ ても、なお神経痛で痛み続ける。乙の痛みは生 体に何の役目をしているかというと、何の役目 あ果たしていない。それはただわれわれを苦し めているだけで、生体に対して何のプラスにも なっていないのです。

また、痛みの強さは、急性痛のときは、病状 に比例するととが多い。とてろが慢性痛（だい たい 6 力月以上たってあ痛いむのを言う）、と の場合は痛みの強さと病状の程度は比例しませ ん。また慢性痛は自律神経の機能低下を来たし ます。すなわち、食欲がなくなり、眠れなくな り、性的機能は衰え、いつも疲労感があり、運 動障害が起こる。

また、精神的には、急性痛のときは不安になる のですが、慢性痛になると抑うつ状態になる。そ のために余計自律神経失調状態がひどくなる。

要するに慢性痛は患者の全生活を破壊し、そ の人間性を根本的に失わしめるととになりま す。そしててれが社会的犯罪の原因にもなり得 るわけです。

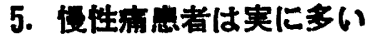

先ほど医者の間にあ、痛みというのは単なる 
症状に過ぎない、という見方が強く、痛みを軽 視しているというととを言いましたが、いま痛 みの専門医というのも、実はほとんどいませ ん。日本で痛みを専門にやっていらっしゃるお 医者さんは、最近どんどんふえてはいるが、大 阪でせいせい2 30人ぐらいではないでしょう か。

ととろが慢性疼痛患者というのは実に多いの です。

アメリカのN I Hの統計だと、アメリカには 2 億国民がいますが、その 3 分の 1 が頭痛、腰 痛、関節痛などで悩んでおり、それによる損失 は日本円にして年に 1 兆 2 千億円にのぼる言 っています。いま「ガンだ、ガンだ」と騒いで いますが、アメリカでもガンの患者は80万人し かいません。

\section{6. 橧みに関する民族感情の䢖い}

痛みをどうとらえているか、そのとらえ方は 国によってそれぞれ違います。フランス人は痛 みがあると、それを人のせいにして、「てれは 医者梏さないからいけないのだ」とか、「女 房がいけないからた」とか、そういう感覚でと らえているそうです(四2)。

アメリカ人は非常に割り切っていて、「痛み は悪いインディアンなので、徹底的に亡ほさな ければいけない」というととなのです。痡みを とるととは良い騎兵隊のジョンウェインなので す。だからアメリカでのアスピリンなどの鎮痛 剤の使用量は非常に多い。

日本人はどうかというと、おしんの国ですか ら日本の場合、耐えるというととが道徳です。

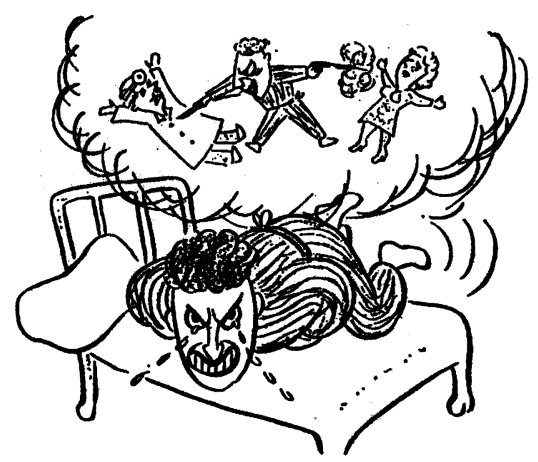

图 2
痛みについてあ、子供のとろから耐えるととを 教えられている。子供が痛い思いをして、泣て うとしてす、泣かしてくれない。母親は泣いち やいけませんと苗う。母親は子供の痛いのがよ くわかりますから、悲しくなるのですが、自分 あそれに耐える。そういうととが良しとされる わけです（因3）。

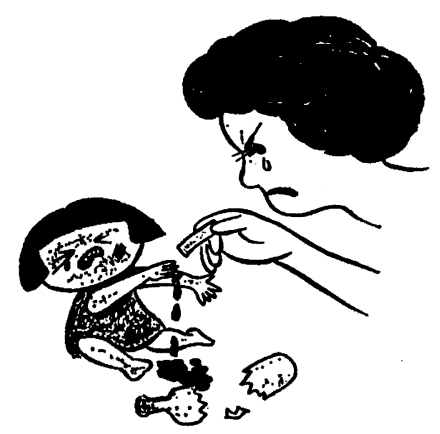

园 3

だからわれわれ医者す、患者付しては、痛 みによく耐えているのを、ちょっと衰めてあげ るという懸度で接してやらないと、あの医者は 不親切だと言われかねないわけです。

それでは日本人以外のほかの東洋人はどうな のかというと、中国とか、ほかの東南アジアな どでは、子供がまだ小さい 6 歳とか 7 嵅まで は、自然に自分の感情を出すととが許されてい て、痛かったら遠慮会䣋なく泣いてもかまわな いのです。子供のときから痛いのをがまんしな さいというような教え方はしていない。痛いの を子供のときからがまんさせるのは、日本だけ なのです（図4)。

しかし痛みというのは、がまんすれば病気が

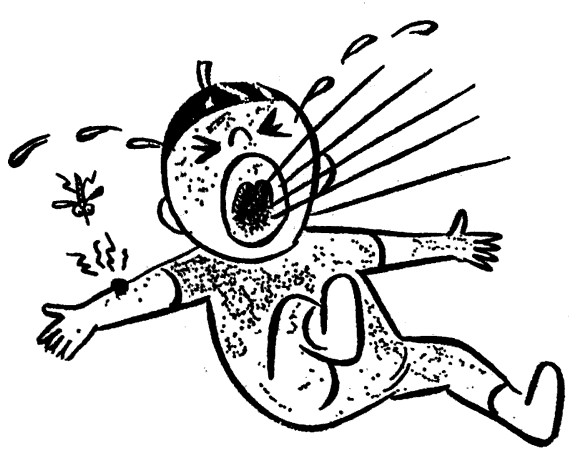

図 4 
早く治るというあのではない。診断さえつけ ば、早く取ってあげなりればいけないものなの ですから、「がまん」は精神修練には良いだろ うが、病気自体に対して良いわけでなく、痛み 自身を徽底的にがまんする必要は毫すありませ ん。

\section{7. 来みの感受性の廷い}

痛みの感じ方ですか、これは個人によって、 また状況によっても逢ってきます。

まず、男と女ではどうかというと、とれは疼痛 域值というもので調へるのですが、多くの研究 の結果は「女性のほうが痛がり」というととに なっています。なぜだというととはわかりませ んが、「痛みを早く感ずるほうが、神経が発達 しているのだ」ということであれば、男性より 女性のほうが「良くできている」ということに なるのかすしれません。

それから年齢の点から言えば、65歳過ぎの老 人になると、痛みに関する感受性はにふくな る。

一方、産まれたばかりの赤ちゃんは、昔は、 痛覚の発達がにぶいと言われ，麻醉をしないで 手術をしたりしたのですが、いまは研究の結果、 おとなより倍くらい、痛みに対して敏感なんだ と言われています。現在は技術も進みましたし、 すへてて全身麻醉をして手術をしています。

また職業によって、痛みの感じ方が量います。 ビルの中で仕事をしているオフィスマンとか $\mathrm{O}$ しは、ちょっとした刺激をすぐ痛みとして感じ ますが、農民とか漁夫は、いつも刺激を受けて いるせいか、痛みに対して抵抗が強い（因5)。
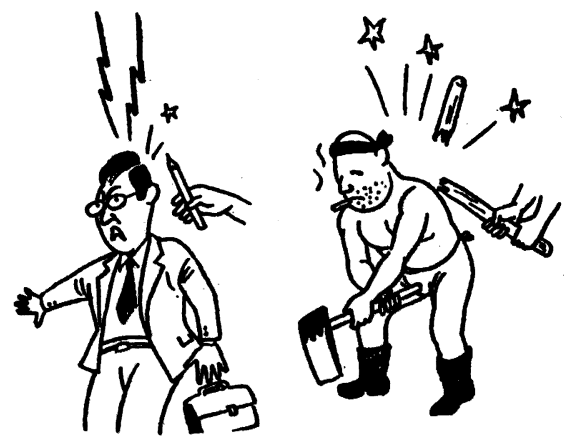

図 5
それから子供のとろにうんと痛い思いをする と、その人は成人してから痛がりになるという 説があります（図 6)。とれは 外国の研究です か、資しい家庭に䏍った人は、幼い頃から痛み の経験をずいぶんしているので、成人すると、 痛みの感受性が人より強いそうです。一方、お 金持ちの子供はおっとり育っているので、成人 した場合、痛みに対する抵抗が強いというとと が言われています。

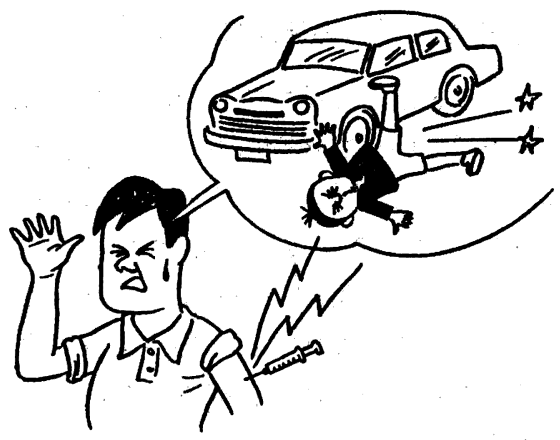

図 6

\section{8. 有虎について}

皮庙の感覚には触覚、温覚、冷覚、痛覚、と 4 つあります。そして触点、温点、冷点、痛点 という、それそれの感覚に敏感なポイントが皮 府上にあります。痛みというのは生体の防衛反 応上必要ですから、痛点というのは非常に多 い。触点はそれに比へると 4 分の 1 ぐらいしか ない。冷点というのはそのまた 4 分の 1 くらい しかない。温点にいたっては痛点の百分の 1 く らいしかない。

そして、自由神経終末と言って、神経線維の 一番末梢か、単なる枝わかれをしていて何の特 別の装置すついてない神経がありますが、てれ が痛みを伝える神経なのです。先に玉ネギみた いのが付いた神経がありますが、とれは触覚や 温覚を伝えるものです。とういうように痛覚、 触覚、温覚、冷覚を伝える神释はそれぞれ違っ ています。

そして人間の体の部位によって、それぞれの 感覚に強弱があります。

たとえば界は冷点と触点が非常に分布してい ますが、温点はあまり発達していません。 
それから口は痛点と 温点が 発達しています が、冷点、触点は発達していません。

手は触点之温点が発達しています。だから指 の先で物の形状がよくわかる、熱いのあよくわ かる。そのかわり冷さにはにふい。また痛みる あまり感じない。指先があまり痛みを感じ過ぎ ると、そのへんをちょっと触わっただけで、痛 いというととになって、かえってまずいわけで す。

\section{9. 痛みを伝える神释は二種類ある}

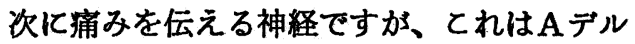
タとC線維という二種類のものがあります（図 7)。Aデルタは細いけれど C線維よりは太く て、鞘をかぶっています。髄鞘というすので す。C線維は、一番細いのですが、まったくむ き出しになっています。とういうように痛みの 神経は二種類あるために、痛みは 2 回、二種類 感じます（図 8)。

たとえば向とうずねを、机の角か何かに強く ぶつけたとします。そうするとまず鋭い、刺す

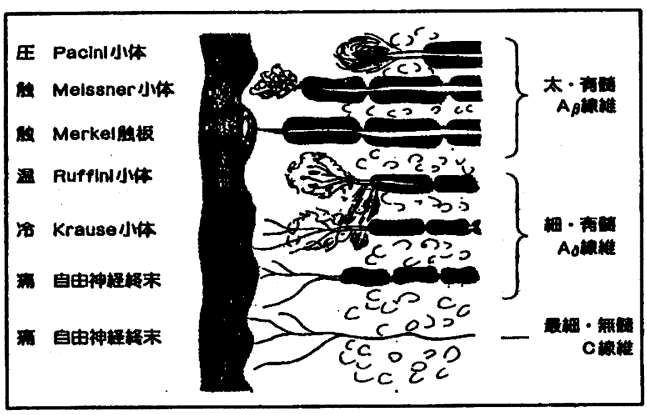

図 7

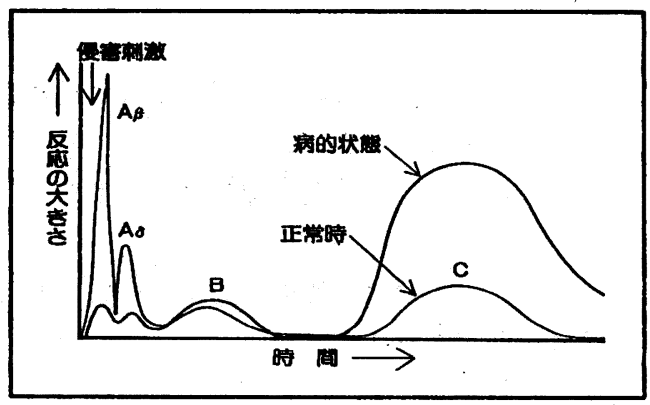

図 8
ようなピリッとした痛みを感じすす。そして一 秒ほど間を置いて、ジワーッとした、持続時間 の長い痛みが次に来ます。最初のピリッとした 痛みは、Aデルタ線維によって伝えられるのて す。あとから来るジワーッとした痛みは、C線 維によって伝えられます。

なせ 1 秒間ほど間隔があるのかというと、や や太い神経のAデルタのほうが、神経の伝達速 度が早いからです。とれは瞬間的に伝わる。一 方C線維のほうは細いですから、1秒間に1メ ートルぐらいしか伝わっていかない。ですから 向とうずねを強く打ってから、1秒ほどたって から、やっと脳のほうに到達する。

\section{0. 痛いと腹がたつ理由}

次痛みがどうやって伝わって、脳に行くか ですか、感じた痛みの刺激はまず脊逞に伝わ り、それが脊䯣のとてろで反対側に行って、脊 髄を上行して、脳にまで行くのですが、その伝 わり方に二つあって、脊䯣の内側のほうを通る のが、C線維で主に構成されたコースです。

てれは途中視床下部之か、そのへんを広く大 脳辺縁系と言いますが、その大脳辺緑系のあた りて、いっぱい枝分かれし、あるいは中継点を 経ながら、脳で広くそれを感じ取って痛みとし て認知するわけです。

一方、あうひとつ、脊䯣の外側のほうを通る コースがあり、これはAデルタ線維で構成され る性兵のあのです。これは途中でほとんど中継 点もなく、枝分汃れするととなく、素值に脳の 上のほうまで伝わっていきます。ストレートの コースが、防衛反応任必要な痛みなので、てれ がなくなると、先ほど言いました先天性無痛症 みたいにまずいととになります。

C線維で伝わるジワーッとした痛みは、大脳 辺縁系で枝分かれし、中継点を通ったりするの ですが、との大脳辺縁系というのは何をしてい るとてろかというと、これは本能と、自律神経 の機能と、それから感情を司っているととろで す。痛みがあると何で腹が立つのか、何で不安 になるのかというと、それはC 線維をのぼって きた痛みが、途中で大脳辺緑系のそういう反応 を起とす部位を通るからです。それで怒った 
り、いらいらしたりする(図9)。

同時にその刺激によって自律神経の反応も起 とりますから、顔が真っ赤になったり、冷汗を 功たり、涙が出たりします。

\section{1. 関连扁}

痛みには 関連痛という現象があります（四 10)。

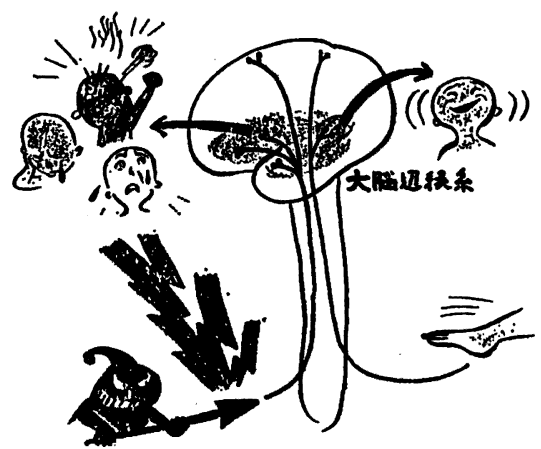

四 9

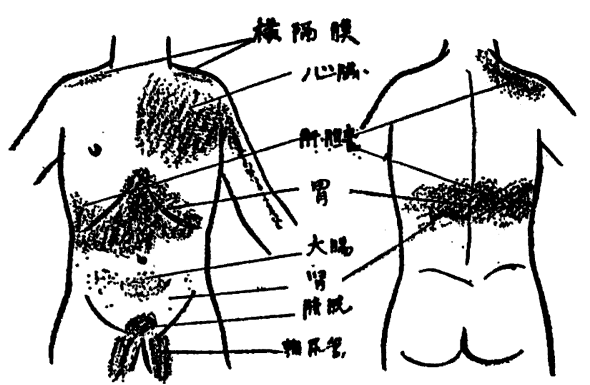

肉速痛

図 10

たとえば心臟が悪いときに、その痛みが左の 前胸部、それから左の有加ら腕にかけて広がり ます。胃が悪いときには、胃の前のあたりと、 背中の胃の後ろのあたりが過敏になって、そと も痛くなってきます。留䐬だったら下腹部に、 輸尿管だったら大腿部の内側飞痛みが放散しま す。

そういうのを関連痛と言うのですが、そての 皮庯の部分は過敏になっており、ジワーッと汗 がにじみ出ていたり、自律神経反応を起てした りしています。

なぜそういう関連痛の現象が起こるかという と、例えば胃が悪いときには、その痛みの刺激
が脊能にはいります。そうするとそれと同し脊 骮の高さのととろにはいってくる皮庙加らの神 経とそこで混同をして、その胃の痛みの刺激か 皮庸のほうに行ってしまうわけです。そのため にそての皮消が過敏になるのです。

したがってての関連痛というのは、病気の猃 断上、また治港上飞あ非常飞役に立ちます。虫 垂炎のときは下腹部が痛む、また胃溃第のとき は背中のだいたい決った場所が病みます。そう いうようにある矢病の関連痛の場所之いうの は、決まっていますから、それが部断の助けに なるわけです。

また治療的にあ、過敏になった皮府の部位 に、ある刺激を与えてやれぱ、それが逆のコー スを通って胃のほうに行きますから、その場合 良い刺激を与えてやれば、胃の病変を治すよう に、ホメオステーシス（自然治虑力）加働きま す。

だから体表面から深部の病気を治すととがで きるわけです。マッサージや指圧をしたり、八 リや炎によって病気を治すというのは、ての関 連崅の原理、皮席加ら逆のコースを通って、治 療刺激を内埛に送り、ホメオステーシスによっ て病気を治す原理を利用しているわけです。

\section{2. 㴋みの强さは测れるか}

さて、いままでいろいろお話ししてきました か、「痛みというあのの程度は、测れるか」と いうことてす(四11)。

痛覚というのは、先天性無痛症てない限り、 誰にでもあります。だから誰であ知っている感 覚であるわけですが、てれは他人と共通侍つ

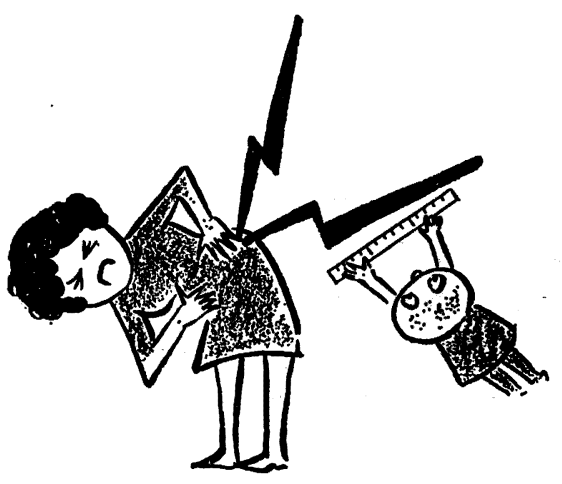

図 11 


\section{ことはできません。}

視党、聴賞、味賞、触賞、この4 感は、他人 と共通に持つことができますが庯みはあくま で主観的な感覚で、個人の体験を出るととがて きない。人の痛みは絶対にわかりません。「痛 い痛い」と言って苦しんでいる人を見てす、痛 がっていて可哀想だなと思うだけで、その痛み をとすにするととはてきません。

だから、痛いという場合、その痛みの程度を 知りたいのですが、てれを客観的に測るととは できない。てれは心の痛みとよく似ています。

しかしどの程度痛いのか、少しは数量的に、 客観的になんとか知りたいすのです。われわれ は痛みを、「少し痛い」とか、「かなり痛い」と か、「とてあ痛い」と加「酎えられないほど痛 い」というふうに表現をしたりするのですが、 とれではあまりにあ大雑把で頼りない。

そこで何とかむっと数量化できないかという ととで、過去いろいろ試みられました。たとえ ば顔の表情です。しかしとれあ痛いからといっ て必ずしも表情を変えるわけではない。では痛 がる声ではどうかというと、外人はキャ一キャ 一と言うからいいかすしれないか、日本人はお しんの国ですからあまり声には出さない。それ では血圧とか、呼吸の変化、眼の変化ではどう 汃々う之、急性疼痛の場合は、そういうあの がある程度反応として出てきますが、慢性疼痛 の場合は痛さとその反応は全く平行しません。 血中にカテコラミンというのが、痛むときには 増えるので、とれを测るのはどうかというとと ですが、これあ慢性疼痛の場合は䭾目なので す。

昨年私は、器械屋さんに、「何か痛みを測れ る器械を考えてくれ」と頼まれました。そてで てれはでく簡単なすのですが、こういうものを 考えました。それは10センチの長さの線を引い て、両端にはっきりと区切りを書いて、片っ方 の端は「とれ以上ない痛みの状態」、片っ方は 「まったく痛みのない状態」としておきます。 そして患者に、「いまあなたの痛みはそのどの あたりに位しますか、そてを指で押してくださ い」というのです。すると患者は、その線の例 えばだいたい 3 分の 1 ぐらいのととろを、押し
たとします。するとそてに明りがつく。そして 3 点とかいった標示が出るのです。「てれ以上 はない痛み」が10なのです(図12)。

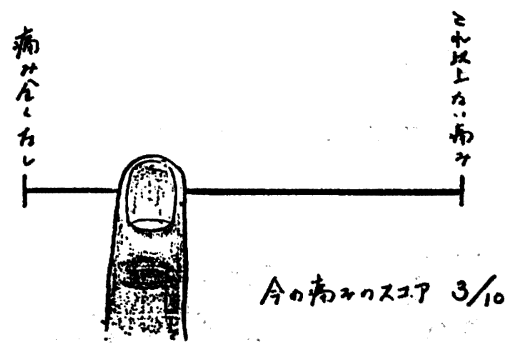

VAS (visual analoque Acale) 12 図

とういう測定方法をビジュアル・アナローグ ・スケール、VAS (視覚相似計)と言います。 しかし仕掛けはいま言ったように、まととに簡 単なあのですから、器械屋さんはたったてれだ けの器械をつくるのですかと言って少々がっか りしていました。しかしてれが痛みを数量的に 表わす場合、いちばん簡単で、敏感で 正確な 方法だというととに、いま世界ではなっていま す。国際学会であ、痛みの強さを表現するの に、みんなとのVASをもとにして「ての痛み は 3 点だ」とか「4点だ」とか言っているわけ です。

\section{3. 萧みについてのゲート・コントロール・ セオリー}

痛みの話をするときに最近、いつす引き合い に出されるのがゲート・コントロール・セオリ 一(門調節系説) です。乙れは「痛みの感覚 は、知覚神経の刺激によって軽減する。また、 脳とか中枢の方からの作用によってもその強さ が影帮を受ける」というととを理論的仿説明し た説なのです。痛いときに、そのあたりを吒い たりさすったりすると痛みがやわらぎ、またス ポーツで夢中になっていると痛みを感じない 一そういった現象を理諭つけたものです(図1 3)。

また、体の方々に 同時に痛みがあるとしま す。たとえば、腰痛と㮏痛と有痛が同時にある 


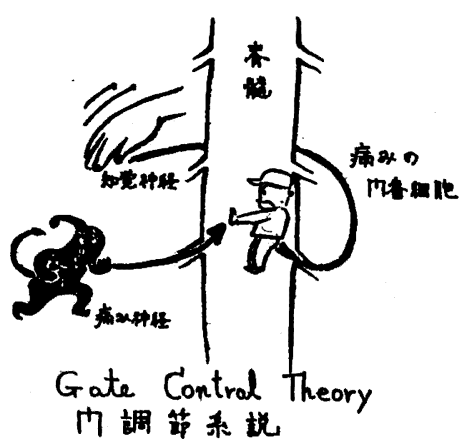

13 这

とします。との場合、痛みの程度が一番高いと ころしか感じていないという現象があります。 たとえば山の一番高い腰痛は感じますが、膝 や肩の痛みは山が低いので、感じないか、弱く 感じているわけです。

そてで痛みの治療に、このゲート・コントロ ール・セオリーと、いまの高い山のととろしか 感じないという理届を利用するわけです。

たとえば蛹いときに蒾を食いしばったり、鉢 巻きをしたり、強く挈骨で押さえたりします が、そういうように体のどてかに強い刺激を与 えてやると、ゲート・コントロール的に痛みの ほうは消える。そういうととは自然に私どすは やっているはずです。

歯の治療というものは、非常に嫌なるのです が、そのとき手に合谷という、ロに関連するッ ボがあるのですが、そとを強く押すとよいわけ です。実際指圧麻酔といって中国ではこういう 方法を抜䨑に利用してます。

もっと強い刺激としては大腿部をつねるのも よい。要するに人工的に作った刺激が矢者さ んのガーガーやる刺激より強ければ、曾のほう の痛みは感じません。これはひとつお試しくだ さい。

\section{4. エンドルフィン}

痛みのメカニズムの研究は、最近ずいぶん進 歩してきました。最近の大きなトピックスは、 「エンドルフィン類」というものの発見です。 エンドルフィンというのは体の中のモルヒネと いう意味です。とれは昭和50年に発見されまし たから、まだほんの10年前です。
アヘンはケシの実から取れ、そのアヘンから の抽出物がモルヒネです。そしててれが非常に 強力な鎮痛作用を持っています。

ではなぜ植物であるモルヒネか人体に対して 強力な作用、つまり強い鎮痛効果を持つのか。 とれは人間の体にモルヒネを受け入れるレセプ ター(受容器)、すなわち、鍵穴があって、そと にモルヒネの分子がピタッとはいり込むからだ と考えられていました。ととろがその鍵穴には いる鍵が何であるかわからなかった。それが昭 和50年に 発見され、化学的に 合成されたのて す。

それはメチオニン・エンケハリン、ロイシン ・エンケハリンという 2 種類の物質で、とれを 内因性モルヒネ様物質之言います。そしてその 後次々にアルファ・エンドルフィン、ベーター ・エンドルフィン、ガンマー・エンドルフィン という、いろんな内因性モルヒネ様物質がある ことがわかってきました。

現在ではその他、ネオエンドルフィン、ダイ ノルフィン、キョートルフィンといった合計20 種類ぐらいのものが明らかにされ、とれらを総 称してエンドルフィンズ (エンドルフィン類) と言っています。要するにてれはモルヒネと似 たような物質が体の中ででき、存在していると いうととです。

てれは中枢神経の特定の部位に沢山存在して おり、正常でもほどほどに常に分泌されていま す。だから私どもは少々変な刺激が加わって あ、それを痛みと感じない。シャツがてすれて あ、風に吹かれても、それを痛みと感じないの は、体の中にエンドルフィンが適当に分必され ているからです。そして一旦緩急のときは、と れが相当大量に生産されて、痛みを感じさせな くする。そのへんは生物の体というのはうまい ととできています。

そてで人工的にてのエンドルフィンを沢山出 させる方法があれば、それを痛みの治療に使え るわけです。実はハリを打つと、エンドルフィ ンが沢山生成されるのです。だからハリで痛み が止まる一つの理由は、とのエンドルフィンの 分泌のためだろうと言われています。低周波刺 激でもとの作用が起とるといわれています。ま 
た適当な運動をすると、エンドルフィンの分必 が促進されると言われています(図14)。

てれは私どすのほうで実験したのですが、た とえば15分ぐらいジョギングをして疼痛計で痛 みの感受性を測ると、痛みに対して30\%ぐらい 抵抗力が増しています。またジョギングを $2 、$ 30分やっていると、ランニング・ハイといっ て、1種の陶醉状感になるのですが、これあエ ンドルフィンの分泌の増加のためだろうと言わ れています。

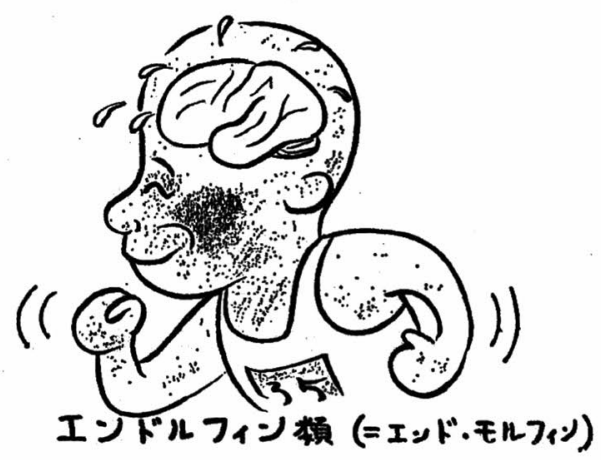

図 14

\section{5. 酒・煙草と痛み}

酒やたばてなどは痛みに対してどうかという ことですが、酒は血行を促進しますから、酸素 の供給が増え、発痛物質が流され、凝りのよう な痛みに有効に作用します。また酒は疼痛域值 を上昇させ、30\%ぐらい、痛みに対して強くな ります。しかし酒を飲んだあとは、反動的に血 管が収縮し、痛みがかえって増すというととが あります。

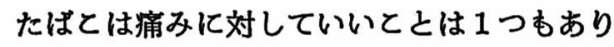
ません。たばとの一酸化炭素が酸素をうばい、 またニコチンが血管を収縮しますから、筋肉の 凝りを悪化させ、慢性の疑りの状感をつくりま す(図15)。

\section{6. 風呂と痛み}

それからお風呂は痛みに対して非常にいい。 血行の改善、代謝の促進、筋肉の弛緩といった あのによって、痛みを柔げ、烧りをほぐします (図16)。

また全身的にあ自律神経が安定し、それによ

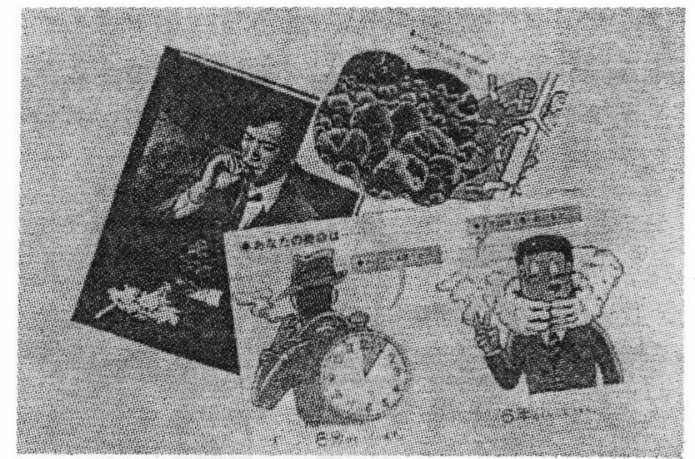

図 15

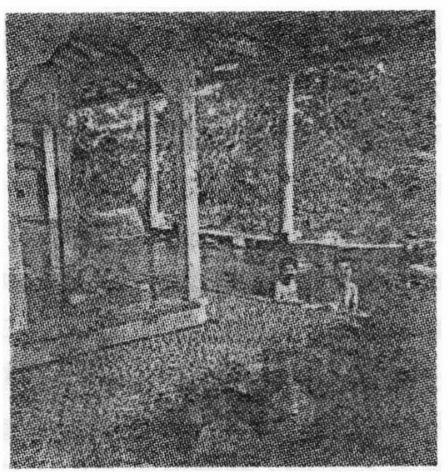

図 16

る鎮痛効果あ期待できます。たとえば三叉神経 痛で痛くてど飯が食へられないという人が、お 風呂の中だと食へららるというととがある。と れは知覚神経のバックにある自律神経が安定す るからではないかと思います。

\section{7. 睡眠と痛み}

次は睡眠との関係ですが、痛みがあると眠れ ません。また、夜中に目が覚めるくらいの痛み というと、ずいぶん痛いということになりま す。

とてろが心因性の痛み、つまり精神的につく り上げた痛みというのは昼間はずいぶん痛がる のですが、寝ているとき痛いと言って目を覚ま すととはない。それは体のどてかが悪くて痛ん でいるのではないからです。

眠りというのは脳の毛様体賦活系の活動の興 奋性の低下によって起とるのですが、痛みがあ るときは、そとを痛覚が絶えず刺激するので、 㡘つくととができない。それであ疲れが出てゃ がて眠るのですが、1 時間ほどするとレム睡眠 
期というのが訪れるので、また痛みが袃ってき て、目を覚ましてしまうわけです(図17)。

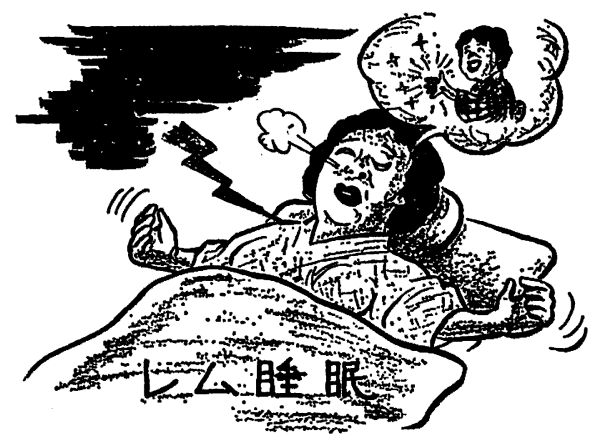

図 17

レム睡眠というのはラビット・アイ・ムーブ メントの略ですが、てのとき目玉がキョロキョ 口動いている。しかしぐっすり寝ていて、莺を 見ています。骨格筋はぐったりしていて、脳波 は覚めているときのようなタイプを示します。 自律神経は全体的に低下していて、呼吸や服が 荒々しくなります。とのレム睡眠は一晚のうち に数回あります。明り方になるほど長くなりま す。そしてとのレム睡眠が終わったときに起き ると非常に爽快です。

しかしレム睡眠のときはいま言いましたよう に自律神経が低下をし、乱れますので、このと きに痛みがよく起とるし、また重篤な病気の発 作が起てったりします。

そとで寝ているとき痛みが起てらないように する一つの方法は、とのレム睡眠を減らせばい い。それにはアルコールを少し飲んだり、トラ ンキライザーを飲んだり、睡眠剤を飲めばいい わけです。

\section{8. 注意転換と蒲み}

痛みというのは心理的影響が非常に大きい。 夢中でスポーツをやっていると、すどいけがを してる、痛みはない。乙れは運動をするとエ ンドルフィンが沢山分泌したり、疲労したとき には疼痛域值が上昇するというとともあります が、注意転換によって、痛みを感じさせないわ けです。

また反対に恐怖とか不安というすのが、痛み に対する感受性を増大させます。そういうよう
に心理的なものが痛みに非常に影響します（図 18)。

痛みに対する注意転換の方法としては、音楽 を聴かせたり、楽しい物語りを聞かせたり、あ るいは「一つ、二つ」と大きな声で勘定させる とそっちに注意が行って、それだけであ痛みが 軽くなります(四19)。

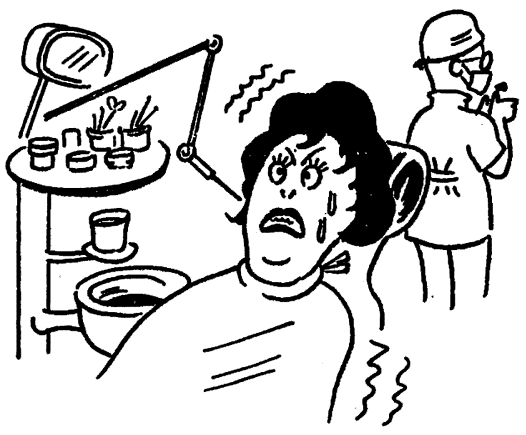

図 18

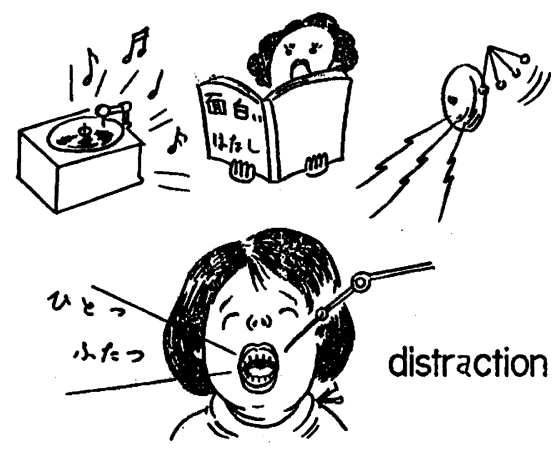

図 19

音楽ではどういうのが痛みにとくにいいかと いうと、アメリカで調べた結果では、ワグナー の「タべの星」「森のささやき」、゙ートーベン の「月光の曲」、ドビッシーの「月の光」とい うのが、効果があったそうです。

日本では演歌で、「津軽海峡冬景色」がいち ばん効果があったというととです。

だから痛みのひどい患者さんには、環境す大 事で、病室もきれいな壁で、看護をしてくれる 人はいつあにとやかで、どとからともなくふく よかな風が吹いてきて、いいにおいがする。そ して枕元にはきれいな音楽が聴てえてくるとい うことだと、痛みす和ぐわけです。 


\section{9. 涌みは孤独}

しかし痛みのひどい患者さんというのは、碓 にもその痛さというものをわかってあらえない し、また誰あ他人の痛がっているのを見ている のは嫌ですから、痛みのひどい患者さんからは、 だんだんと遠ざかります。ですからどんないい 病室にはっていてあ、坬独なのです（図20）。

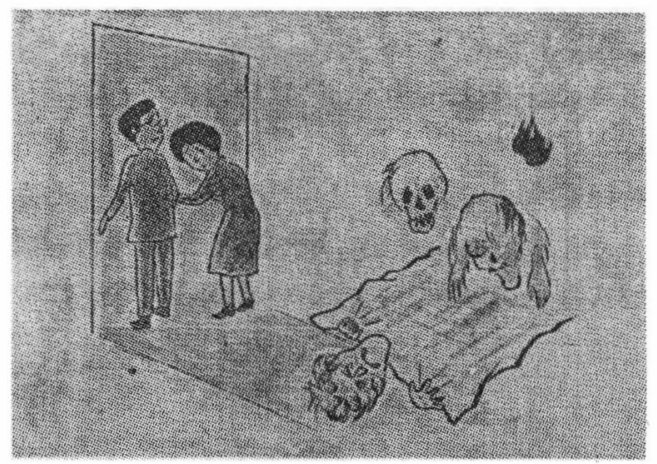

図 20

アリストテレスは「痛みは魂の苦悩である」 と言いましたが、痛みがあると、それは必ず心を 傷つけます。心が傷つくと、それが痛みを助長し ます。そういう悪循環に陥ってしまうわけです。

\section{0. 兵士の悔は痛まない}

アメリカのビーチャーという人が、朝鮮戦争 のとろに、同程度のけがをした人を、兵隊さん と、一般市民とそれぞれ 150 人について、外傷 後 4 時間から12時間の間に調べたととろ、強力 な鎮痛剂を必要とするほど痛がった人は、兵隊 さんのほうは30\%だったが、一般市民のほうは 80\%以上いたというのです(図21)。

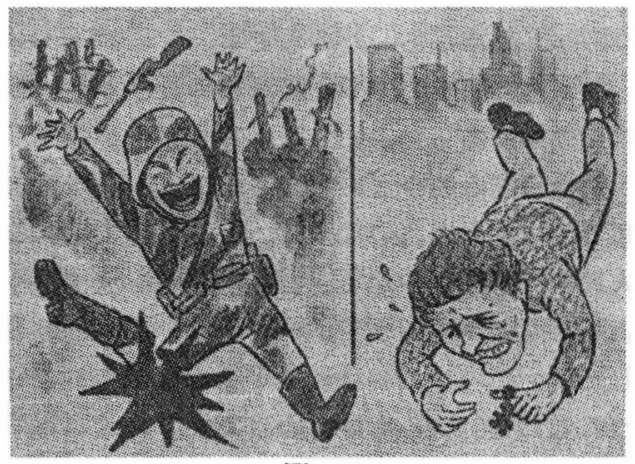

図 21
というととは痛みというのは傷の大きさとは 無関係で、その傷が何を意味しているかで、そ れは違ってくるというととなのです。兵隊さん は足が吹っ飛んであ、そのととによってあう戦 争に行かなくていいからむしろ喜んでいる。と ころが一般市民のほうは、けがによる生活の不 安というとと加ら、その痛みを猛烈に増加させ てしまうわけです。

ですから不安とか、恐怖が痛みを增悪させま す。また痛みに負けて落ち込むと、あるいは痛 みに注意を集中すると、痛みは強くなります。

\section{1. 心因性の痛み}

それから先ほどちょっと言いましたが、心因 性の痛みというあのがあり、肉体的な原因がな くてあ、痛みを自分でつくるととができます。 そういう痛みは、身体的異常を知らせるアラー ムではなく、それは感情の表現として利用され ているわけです。

たとえば自分にとって大事な人から迫害を受 けたとき、あるいはそういう人を亡くしたとき、 痛みがきます。また自己徴畍ということであ痛 みがきます。さらに逃避というととで痛みがく るととがあります。学校に行く時間になると、 子供がお腹が痛いというのは、その典型です。

そういうことで肉体的な痛みがあった場合、 それが不安と加、恐怖とか、注意集中とか、痛 みに負けてしまうというととによって、増悪さ れ、その上にいまの心因性の痛みが加わるとと によって、痛みというものを、ますます複雑な あのにしていくわけです。

\section{2. 心理効果の重要性}

プラシーボ効果というのがあります。疑薬と いうものです。たとえばお砂糖でも何であいい ですから、「てれで痛みが止まるよ」と言って、 それを何加の楽のように装って与えると、実際 勃くととがあります。

そしてすへての治療法において、とのプラシ 一ボ効果は30\%ぐらいあるというととになって います。ある梖で、痛みが、本当に治るという ととを証明するのには、その倍の60\%以上に効 果がなりればいけないのです。 
昔の医術というあのは、とのプラシーボ効果 というものを大いに利用しました。いわゆる呪 術というあのがそれです。いまです巫子とか霊 媒が呪術で病気を治したりしています。現代の 医学にあ限界がありますから、そてにそういう ものがはいってくる余地があるわけです。

たとえば梵字で書いた痛みを取るおまじない というのがあって、それを書いて枕元に置いて おくと、痛みが治るというのですが、心因性の 疼痛の場合には、そういうすのが効果を現わす ことがあります(図22)。

いまの医学というのは科学万能主義で、そう いう心理効果というるのを無視しているとてろ があるのですが、呪術とまでいかなくとす、と れからは痛みに対しては特に、心理的、精神的 な面をうんと配虑して、治療に当たるべきだと 思います。

\section{3. 庯みは取り去るべきもの}

正岡子規は結核性瘦孔で、最後の数年間は非

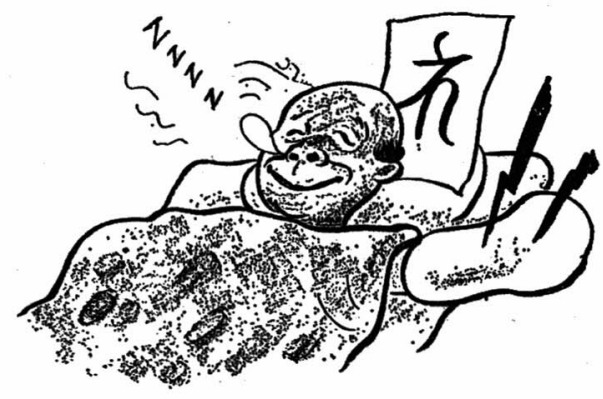

区 22
常な痛みで苦しみました(罒23)。

痛みの激しいときは泣きわぬき、果ては「早 く死んでしまったほうがいい」と思うと、その 手記に書いてあるのですが、「痛みが減ずると、 とたんに死にたいと思ったととなどケロッと忘 れてしまう。こういった平和な時間が少し続い たときに、ふと死というととを思い出すと、常 人と同じように呼な気持ちになる、人間という あのは現金なあのである」、というようなとと を彼は書いています。

そういうように痛みというのは、それが存在 するときには、全人格を破壊し、痛み以外のと とを何も考えるととはできなくなります。しか しそれを除去したあと、幸い痛みによる後遺症 は残らないのです。痛みというあのはなくなっ てしまいさえすれぱ、それでいいのです。

そういうことからあ「全人間的な医療」にと って、痛みの除去というととがいかに大切かと いうことが、おわかりいただけると思います。

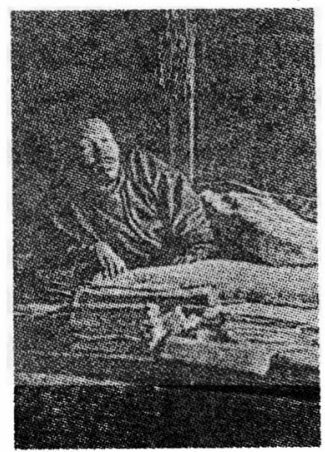

図 23 